Святослав О. Вербич

Інститут української

мови НАН України*
UDK 811.16'373.21(282.247.314):811.13

DOI: 10.4312/linguistica.55.1.115-129

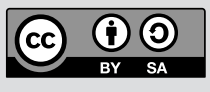

\title{
СЛОВ'ЯНСЬКО-СХІДНОРОМАНСЬКА ВЗАЕМОДІЯ В ГІДРОНІМІЇ БАСЕЙНУ ДНІСТРА: ОРИГІНАЛЬНІ НАЗВИ ТА СТРУКТУРНО АДАПТОВАНІ УТВОРЕННЯ
}

Українська Наддністрянщина належить до тих історично-культурних ареалів, у межах яких у різні часи (доісторичні й історичні) відбувалися мовні контакти слов'ян із неслов'янськими етнічними угрупованнями (переважно індоєвропейськими). Природно, що така міжмовна (міждіалектна) взаємодія позначилася на словникові місцевого населення - як на його апелятивному, так і на онімному складникові (передусім на системі різних власних географічних назв, зокрема гідронімів - найстійкіших у часі nomina propria). Лінгвістичне дослідження гідронімікону Дністра на діахронному рівні уможливлює виділення в його складі утворень, сформованих унаслідок українсько-румунських і українсько-молдавських контактів. Вони представлені в різних частинах басейну Дністра - верхній, середній і нижній. У верхній і середній течіях Дністра, що охоплюють Прикарпаття, фіксуємо назви, які виникли в результаті українсько-румунської та українсько-молдавської (в межах Буковини) взаємодії. Поява румунських мовних елементів у цьому регіоні зумовлена волоською колонізацією Східних Карпат. Це було тривале в часі переміщення пастухів-волохів із центральних районів Трансільванії на північ Карпат, що завершилося в XVII ст. у Моравії (Клепикова 2007: 309). Дослідники цього питання неодностайні щодо встановлення початку цієї міграції. Так, Й.О. Дзендзелівський уважав, що вона почалася приблизно в XI ст. і продовжувалася в XIII-XVI ст. (Дзендзелівський 1959: 112). М.А. Мохов початкову дату розселення волохів пов'язував із ХІІ ст. (Мохов 1978: 83-84), Ю.В. Шевельов і Г.П. Клепикова - із XIII ст. (Шевельов 2002: 988; Клепикова 1976: 25), К.Ф. Герман - із серединою XIV ст. (Герман 2010: 38). Очевидно, що переміщення волоського населення зі свого трансільванського осідку не могло початися раніше другої половини ХІ ст. Історія свідчить, що переселення волохів спричинив натиск угорського етносу, який наприкінці XI ст. розширив свій вплив на східні території (Еремия 1990: 21). Розбіжність у колі дослідників щодо датування початку міграції волохів на північний схід викликана, напевно, тим, що вони (дослідники) брали до уваги різний час проникнення східних романців на давньоукраїнські терени - раніше на Закарпаття, трохи пізніше (через карпатські

\footnotetext{
* 01001, Київ, вул. М. Грушевського, 4, Інститут української мови, к. 608; sviatoverb@ukr.net
} 
перевали) у Прикарпаття. Важливо, що наслідком цієї колонізації була українсько-румунська міжмовна і міжкультурна взаємодія, яку сьогодні відбивають контактні українські закарпатські, гуцульські, покуто-буковинські і наддністрянські діалектні ареали (Удлер 1976: 28). Українсько-східнороманські мовні контакти відбувалися і в Нижній Наддністрянщині. Тут також відзначені як румунські, так і молдавські (переважно) мовні впливи. Історія мовно-культурних взаємин українців і молдаван у цьому регіоні сягає кінця XIV ст. Саме в цей період молдавани освоюють межиріччя Пруту й Дністра (Сергиевский 1946: 338). Молдавська експансія на ці й прилеглі землі тривала і в наступні століття. Особливої інтенсивності переселення молдаван зі своєї етнічної території на лівобережжя Нижнього Дністра набуває в 2-й пол. XVIII ст., спричинене політикою Російської імперії, яка заохочувала переселенців на відвойовані від турків території (Тучинський 2007: 33). Отже, східнороманські запозичення в словникові українців Нижньої Наддністрянщини також історично зумовлені.

У сфері нашої уваги в пропонованому дослідженні гідроніми, у структурі яких відбиті східнороманські мовні елементи - цілісні лексеми, основи, афікси, а також назви гідрооб'єктів (генетично слов'янські, тюркські), адаптовані до східнороманської мовної системи.

Кількісно найбільшу групу назв у дністерському гідроніміконі із східнороманськими формальними ознаками становлять утворення, що постали способом онімізації відповідних географічних апелятивів (а також загальновживаних лексем на позначення розміру, форми чи інших якісних ознак гідрооб'єкта) або трансонімізації суміжних топонімів (мікротопонімів, оронімів), похідних від лексем із переважно географічною семантикою. Ці слова (загальні назви) слід кваліфікувати як прямі запозичення в тих українських діалектах (буковинських, гуцульських, закарпатських, наддністрянських, степових), які безпосередньо контактували зі східнороманським мовним середовищем. Проілюструємо викладені міркування конкретними прикладами. У басейні Нижнього Дністра зафіксовано назву р. Гирла (вп. в оз. Катлабуг; Ізмаїльськ. р-н Одеськ. обл.; СГУ 1979: 131), що виникла лексико-семантичним способом на основі апелятива гирла, запозиченого зі східнороманських мов, пор. румун. girlă ‘потік, відгалуження річки' (Герман 1973: 11). Споріднені власні географічні назви відзначені на Буковині ${ }^{1}$ - мікротопонім Гирла (Чеховський 1996: 196), у Румунії топонім Gîrla (Iordan 1963: 120) й Молдові - гідронім Гырла (Еремия 1970: 60-61). Гідронім Гертіп (б., бас. Дністра; с. Гертопи Котовськ. р-ну Одеськ. обл. (СГУ 1979: 130); як Гертоп, л. Тилігулу, бас. Дністра; Зеленко, Касім 1999а: 91) утворений на базі укр. діал. герті́n, гирто́nи (у множині) 'яри, вибоїни' (ЕСУМ 1: 509), одеськ. сирто́n 'назва частини села на горах, вибоїнах' (СУГО 2011: 52) < молд. хыртоп 'вибоїна', румун. hirtop 'т. с.' (ЕСУМ 1: 509; Павлюк 1969: 77-78). ${ }^{2}$

1 Східнороманський внесок у буковинську топонімію досить значний, найповніше проявився в період XVI-XVIII ст. (Карпенко 1973: 214).

2 У слов'янському топоніміконі органічні назви на зразок укр. Bepmín (бас. Дністра; с. Яблуниця Надвірнянськ. р-ну Івано-Франківськ. обл.; СГУ 1979: 98) < верте́n 'печера; непрохідна ущелина; провалля; балка з болотом’ 〈псл. *vbrtъpъ (ЕСУМ 1: 35). 
У гідроніміконі Дністра зафіксовано чимало романізмів, семантика основ яких мотивована різними ознаками (форма, розмір, смак, запах тощо). Назва б. Ларга (л. Кучургану л. Турунчука л. Дністра; Одеськ. обл.; ГНП 1981: 56) - результат української фонетичної адаптації молд. ларгэ 'широка' (ГНП 1981: 56-57) зі зміною молд. э > укр. $a$ (Удлер 1967: 179), пор. ще топонімні паралелі: буковин. p. Ла́рга (л. Пруту л. Дунаю; Чернівецьк. обл.; СГУ 1979: 310), румун. топонім Larga (Iordan 1963: 114). Гідронім Миндра (б., л. Кошарки, пр. Кучургану л. Дністра; Одеськ. обл.; ГНП 1981: 62) < молд. миндрэ 'гарна' з дальшою зміною кінцевого молд. э > укр. a. Назва р. Сарáma (вп. в лиман Сасик між рр. Прут і Дністер; смт Сарата Одеськ. обл.; СГУ 1979: 487) - адаптована на українськомовному грунті прикметникова форма від молд. сэрат 'солоний' - дериват із суфіксом -am- (щодо інших утворень гідронімного рівня з цим формантом пор., наприклад, назву р. Аленгата в бас. Серету (молд. ален- 'поволі'; Карпенко 1973: 23) від іменника cape 'сіль' (Сергиевский 1946: 343). Топонімні аналоги поширені як в українських регіонах зі значним східнороманським мовно-культурним впливом - гідроніми Сарата в бас. Пруту (Івано-Франківськ. і Чернівецьк. обл.; СГУ 1979: 487), так і на території Румунії: численні топоніми Sărata Baniului, La Sărata, Sărata-Coman, Poiana Sărata та ін. (Iordan 1963: 125-126). 3 огляду на словотвірну структуру гідроніма Сарата й ареал споріднених утворень на території Румунії малопереконливою видається гіпотеза Р.М. Козлової про слов'янське походження назви Capama <псл. *saratb < *sar-<i.-є. *ser- 'текти, рухатися'. За версією дослідниці, молд. сэрат, румун. sărat - запозичення зі слов'янських мов (Козлова 2006: 205206). Назва рр. Стри́мба (1) л. Ворони п. Бистриці-Надвірнянської п. Бистриці п. Дністра; поч. у м. Надвірна; нп Стримба, Лісна Тарновиця, Перерісль, Камінна та ін. Надвірнянськ. р-ну; Нижній Березів Косівськ. р-ну; 2) пр. Люшецького л. Свічі п. Дністра; с. Новошин Долинськ. р-ну Івано-Франківськ. обл.; СГУ 1979: 533). У цьому ж регіоні зафіксовано також ороніми Стримба « місцевого стримба 'стрімка гора' (Габорак 2008: 368), що може вказувати на вторинність гідроніма Стримба стосовно відповідного ороніма. Однак ознака 'крива', відбита в румун. strimb 'кривий' (Нrabec 1950: 74, 139), може свідчити і про первинність гідроніма, як, до речі, вважав О.М. Трубачов (Трубачев 1968: 263), пор. у цьому контексті типологічно споріднені укр. гідроніми з основою Крив- у різних регіонах (СГУ 1979: 283-287).

У прикарпатській частині бас. Дністра відзначено ряд гідронімів, що виникли способом трансонімізації ідентичних назв орооб’єктів. Вони мотивовані відповідними географічними апелятивами. 3 цього приводу зауважимо, що східнороманські елементи в словникові населення досліджуваного регіону, крім інших тематичних груп, досить часто представлені в лексиці на позначення об’єктів гірського ландшафту. Це зумовлено тим, що географічна номенклатура безпосередньо характеризувала природне середовище перебування пастухів-волохів (Десницкая 2004: 302). Так, на відоронімне походження гідроніма Грун (потч., л. Стрия; с. Верхнє Висоцьке Турківськ. р-ну Львівськ. обл.; Матіїв 1999: 18) вказуе географічний апелятив грун 'горб', 'горб на схилі гори', який має фонетичний 
варіант трунь 'вершина гори', 'гірський хребет', 'гора, покрита лісом' (Марусенко 1968: 225). Цю лексему вважають запозиченням із румунської мови (ЕСУМ 1: 606; Gołąb 1959: 300-307; Клепикова 1972: 93-94, 106). Щодо варіантності г/є у грун(b)/грунь, то вона може свідчити про два періоди запозичення цього слова з румунської: 1) давніший (до ХІІІ ст.), коли іншомовне $g$ в українських (карпатських) і словацьких діалектах перейшло в $2, h ; 2)$ пізніший: іншомовне $g$ було засвоєне в контактних із румунським середовищем українських діалектах як чуже й передавалося фонемою $\tau$ (Gołąb 1959: 304-305). Очевидно, що укр. (карпат.) грун(ь) було запозичене зі східнороманських говорів ще до XV ст., оскільки після цього періоду, як зазначає Р.Я. Удлер, румунське $n$ > $j$ Удлер (1976: 31). Відомі також спроби з'ясувати походження карпатського оротерміна грунь і на слов'янському грунті (Герман 1973: 11; Куркина 1979: 53; Карпенко 2005: 19-20). Основним аргументом прихильників слов'янської генези лексеми грунь було ії поширення в різних слов'янських мовах, зокрема в несуміжній із українськими карпатськими говорами російській, а також широкий ареал (понад 200) похідних топонімів у слов'янських Карпатах. Однак ареальний чинник не завжди вказує на питомість того чи іншого апелятива на певній території. Щодо гідронімів Грунь, відзначених на Лівобережній Україні, а також на території Росії (WRG I: 532-533), то ці назви постали на основі оротерміна грунь, перенесеного на лівий берег Дніпра внаслідок переселення українців із Прикарпаття в XIV-XV ст. (Стрижак 1965: 178-192). Етимологічний аналіз апелятива грун(ь) дає більше підстав уважати його румунізмом (< лат. *grunnium (Удлер 1976: 31) > рум. grun 'свиняче рило’ (Gołąb 1959: 307), яке перейшло у сферу географічної термінології, набувши метафоричного значення 'пагорб, узгір'я', ${ }^{3}$ пор. ще топоніми Grunjul < grunj 'шматок землі, брила’ на території Румунії; Iordan 1963: 30), аніж зближувати з псл. * grQda (Герман 1973: 11). Викладене вище схиляє до думки, що географічний апелятив грун(ь) поширився в Східних Карпатах унаслідок волоської колонізації (Gołąb 1959: 306). Назва пот. Мárypa (п. Сигли п. Опору п. Стрия п. Дністра; с. Либохора Сколівськ. p-ну Львівськ. обл.; Матіїв 1999: 44) - трансонімізована форма суміжного ороніма Ма́zура (с. Опорець Стрийськ. р-ну Львівськ. обл.; ОАІУМ) < географічного апелятива магура 'висока гора' (Марусенко 1968: 236) < румун. măgúră 'гора, височина, горб’ (ЕСУМ 3: 356), пор. ще топоніми Мэгура на території Молдови (Сергиевский 1946: 348) < молд. мэгурэ 'гора, горб' (ЕСУМ 3: 356).

В основі ряду топонімів, твірних для дністерських гідронімів, виокремлюємо лексеми, які з огляду на свою семантику характеризують не гірський рельєф, а місцевий тополандшафт. Гідронім Се́куль (пот., пр. Рожанки п. Опору п. Стрия п. Дністра; с. Верхня Рожанка Сколівськ. р-ну Львівськ. обл.; СГУ 1979: 493) Я. Рудницький виводив від румун. secul 'сухий’ (Рудницький 1962: 77). Однак таке пояснення неостаточне $з$ погляду мотивації апелятивної семантики основи наведеної назви. На це вказує, зокрема, інше значення апелятива секуль, пор. молд. секуль 'вік, століття' (МРС 1961: 566) 'старий'. Очевидно, назва гідрооб'єкта

3 Стосовно схожого переосмислення семантики (частина тіла $\rightarrow$ географічне поняття) пор. псл. *rъtъ 'рот, дзьоб' $\rightarrow$ 'мис, виступ' (ЕСУМ 5: 127). 
Секуль вторинна щодо суміжного ороніма (пот. Секуль починається на схилі гори Секуль; SG X: 421), пор. ще споріднену назву пот. Secul у бас. p. Сучави (SG X: 421; p. Сучава тече в Україні (на Буковині) та Румуніі), типологічно співвідносні стосовно мотивації ознакою 'старий’ карпатські ороніми Cmapá, Cтари́ŭ (Габорак 2008: 360). Гідронім Че́рбуль (пот., п. Лімниці п. Дністра; с. Ясень Рожнятівськ. p-ну й смт Долина Івано-Франківськ. обл.; СГУ 1979: 603) Р.М. Козлова етимологізує в колі споріднених, на іiї думку, назв, як-от: блр. Чербы, рос. Чербышева - ойконіми, виокремлюючи в них спільну основу Черб- <псл. *čbrb- < і.-є. * $(s) k e r-$ 'гнути, згинати' (Козлова 1997: 125). На наш погляд, основа гідроніма Чербуль генетично не пов'язана з основою Черб- згаданих білоруського і російського ойконімів. Уважаємо, що гідронім Чербуль слід аналізувати в місцевій топонімній системі, у якій представлено також оронім Чербуль - дериват від рум. cerb 'олень' (Габорак 2010: 494), оформлений суфіксом-артиклем чол. р. -ул(b). ${ }^{4}$ На підтримку такої етимології наведемо українські прикарпатські оронімні відповідники з основою Олен(ь): Олени́ия, Оле́нячий ка́мінь (Габорак 2008: 265).

Кількісно меншу групу, порівняно 3 відапелятивними і відтопонімними гідронімами східнороманського походження в бас. Дністра, становлять назви гідрооб'єктів, похідні від молдавських (румунських) власних особових назв. Здебільшого такі гідроніми позначали невеликі об'єкти, сигналізуючи про належність території, де вони локалізовані, певному власникові. Частина цих назв зазнала словотвірної адаптації на слов'янському грунті, на що вказує присвійний суфікс -ов- у їхньому складі. Інші гідроніми ілюструють східнороманську дериваційну модель, у якій присвійність може виражатися без характерних афіксів. Гідроніми Дегусарове (гирло, що з'єднує оз. Драган із Турунчуком л. Дністра; Одеськ. обл.; ГНП 1981: 29) < антропоніма Дегусар - фонетично адаптована форма від молд. Декусарэ (ГНП 1981: 29), Драган (оз. між Дністром і Турунчуком; поблизу с. Яськи Одеськ. обл.; ГНП 1981: 36) < антропоніма Драган «молд. Дрэгану (ГНП 1981: 36). У деяких дністерських гідронімах посесивність виражена східнороманськими формантами -ул, -оя, наприклад: Дикул (оз. між Миколаєвим і Арсівським гирлами Турунчука л. Дністра; біля с. Незавертайлівки Одеськ. обл.; ГНП 1981: 29) < антропоніма Дику + -ул, Цуиуроя (б., л. Липецької п. Тилігулу між рр. Дністер і Пд. Буг; Одеськ. обл.; Зеленко, Касім 1999: 101) < антропоніма Tuţura (Зеленко, Касім 1999: 101), оформленого суфіксом -оая > -оя в присвійно-відносній функції.

У кожному багатокультурному регіоні взаємодія різних мовних (діалектних) систем проявляється у взаємовпливах на різних структурних рівнях - фонетичному, лексичному, морфологічному. Яскравою ілюстрацією такого лінгвоконтактування $\epsilon$ апелятивний і онімний словники. Щодо гідронімів і топонімів, то вони, входячи в поліетнічномовну топонімну систему такого ареалу, зазнають фонетичної, морфологічної і словотвірної адаптації своєї структури до місцевих назв. У регіоні бас. Дністра виділяємо три групи гідронімів, у структурі яких у різній ком-

4 Означальний артикль -yл(b) - органічний формант у складі румунських мікротопонімів, відзначених в Українських Карпатах (Обручар 2007: 40). 
бінації поєдналися слов'янський, східнороманський і тюркський мовні (діалектні) елементи. Першу групу формують назви гідрооб'єктів із румунськими (молдавськими) твірними основами, оформлені слов'янськими афіксами. Це здебільшого суфікси -ець , -ка, -ськ-, які або підсилюють ознаку, виражену твірною основою, або вжиті в релятивній функції. Гідронім Панти́рецьь (пот., л. Дурнинця п. Гропенця л. Бистриці-Надвірнянської л. Бистриці п. Дністра; тече в уроч. Пантері; с. Зелена Надвірнянськ. p-ну і с. Розтоки Косівськ. р-ну Івано-Франківськ. обл. (СГУ 1979: 411), пол. форма Panterec; SG VII: 846) утворений суфіксальним способом від контактного мікротопоніма Пантері: Пантирець 〈 Пантері + -ець. Мікротопонім Пантері, а також споріднені ороніми Пантир (с. Бистриця Надвірнянськ. р-ну; сс. Микуличин Яремчанськ. м/p, Білі Ослави Надвірнянськ. р-ну), Пантиреш (сс. Брустури, Шепіт Косівськ. р-ну Івано-Франківськ. обл.) мають румунський етимон - географічний апелятив pantă 'схил, спад, укіс' (Габорак 2008: 271). У гідронімі-словосполученні Томна́тищький Звір (пот., пр. Лужанки, бас. Дністра; с. Лужки Долинськ. р-ну Івано-Франківськ. обл.; СГУ 1979: 568) привертає увагу (в контексті порушеної проблематики) атрибутив Томнатицький - дериват із суфіксом -ськ- (зі значенням відносності) від суміжного ороніма Томнатик < румун. tomnatic 'осінній' (Hrabec 1950: 167). Семема 'осінній' характеризувала поняття 'гірське (осіннє) пасовище', пор. ще споріднені відтопонімні гідроніми Томна́тик у бас. Серету й Тиси (СГУ 1979: 568). Гідронім Кримпулька (б., л. Карабану л. Кошарки л. Дністра; Одеськ. обл.; ГНП 1981: 53) має топонімну паралель - назву с. Кримпулька (Фрунзівськ. р-н Одеськ. обл.). Аналіз морфемної структури цих назв дає змогу виділяти основу Кримпул(b), ускладнену суфіксом -ка. Етимологію твірного кримпул(ь) допомагає з'ясувати лексика східнороманських мов, як-от молд. крымпей 'обривок' (МРС 1961: 323) < крымn-, значення якого, очевидно, мотивоване дією рвати. 3 огляду на це семантику твірного кримпул(b) <кримn + -yл(b) відновлюємо як *‘балка з обривистими берегами', пор. споріднений щодо такої мотивації апелятив укр. обри́в 'стрімкий берег' (Марусенко 1968: 238-239). У цьому разі ойконім Кримпулька вторинний стосовно відповідного гідроніма.

До другої групи належать гідроніми, що сформувалися на слов'янському мовному грунті, але зазнали структурної (фонетичної і словотвірної) адаптації з боку контактних румунської і молдавської мов. Назва р. Булата (л. Кайнари л. Реуту п. Дністра; кол. Сороцьк. пов. Бессарабськ. губ.; WRG I: 226) має варіант Болата (Еремия 1990: 74), промовистий щодо встановлення етимології потамоніма. Малоймовірний зв'язок річкової назви Булата з укр. була́m 'гартована сталь, шабля’ (ЕСУМ 1: 289) чи молд. була́m ‘бондарський ніж’ (МРС 1961: 96) через логічну неузгодженість понять 'вода (течія, річка)' і 'сталь (виріб із сталі)'. На наш погляд, первісний гідронім Болата (Булата ‘ Болата внаслідок лабіалізації $o>y$ під впливом попереднього губного) - романізована форма від укр. болото < псл. *bolto, тобто Болата - фонетично видозмінений слов'янський (український) гідронім на території Молдови. Гідронім Зборшо́ра (р., л. Збори л. Болохівки л. Сівки п. Свічі п. Дністра; с. Збора Калуськ. р-ну Івано-Франківськ. обл.; СГУ 1979: 209) О.М. Трубачов відносив до назв із східнороманським оформленням, 
виділяючи в ньому суфікс -шора (Трубачев 1968: 159). Таке пояснення, правильне за своєю суттю, потребує все-таки певного уточнення й доповнення. По-перше, формант -шора (вказував на зменшену ознаку) функціонує як у молдавській, так і в румунській мові (румун. -şoara; Vrabie 2001: 81; Думін 1969: 157). У топонімії Прикарпаття в межах Івано-Франківщини помітний саме румунський вплив, а не молдавський. Тому некоректно виділяти в прикарпатській назві Зборшора молд. формант -шора. По-друге, твірною основою гідроніма Зборшора є контактна назва р. Збора, яку, на противагу М.М. Габоракові (пояснює Збора від румун. zbiera 'ревіти'; Габорак 2010: 174), вважаємо онімізованою формою від апелятива збір (> збора внаслідок узгодження номена збір з родовою назвою річка) < *cъборь 'річка, яка збирає воду', пор. споріднений гідронім Збір у бас. Верхн. Дністра на Львівщині (СГУ 1979: 209). Назва р. Реуцеель (п. Реуту п. Дністра; варіант Рэуцел; Еремия 1970: 63) виникла внаслідок трансформації первісного Рэутулуй (Еремия 1970: 63) з дальшими фонетичними змінами на грунті молдавської мови. Рэутулуй - утворення з демінутивним суфіксом -луй від слов'янського за походженням гідроніма Реym, в основі якого архаїчний (у нейотованій формі) дієприкметник теп. часу реуть (пор. рос. діал. реут 'стара назва дзвону'; Фасмер III: 476) < псл. *revQtъ (Трубачев 1968: 220) < *revQ, *r’uti.

У складі третьої групи аналізуємо гідроніми 3 генетично тюркськими (татарськими) основами, словотвірно оформленими в східнороманському мовному оточенні. Назва пот. Кайнарулуй (нижче Ботни п. Дністра; с. Кайнари кол. Бессарабськ. губ.; WRG II: 189-190) співвідносна із суміжним ойконімом Кайнари і гідронімом Кайнара (р., п. Ботни п. Дністра; WRG II: 189), що дає підстави кваліфікувати гідронім Кайнарулуй як утворення з молд. демінутивним суфіксом -луй від тюркського за походженням гідроніма Кайнара. На це вказують як етимологічно споріднені гідроніми в межах Центральної України - pp. Кайна́p, Кайна́ра в бас. Пд. Бугу (СГУ 1979: 228), так і на тюркськомовних теренах: pр. Кайнар у Киргизії, Казахстані й Туреччині (Мурзаев 1984: 241-242). Наведені потамоніми постали лексико-семантичним способом від географічного апелятива тюрк. кайнар 'джерело' (Мурзаев 1984: 241-242) < д.-тюрк. qajnar 'річка, що вирує’ (ДС 1969: 407-408). Гідронім Кулишора (р., пр. Кули л. Реуту п. Дністра; кол. Бельцьк. пов. Бессарабськ. губ.; WRG II: 603) похідний за допомогою східнороманського суфікса -шора (див. вище) від контактного гідроніма Кула. O.M. Трубачов етимологізував цю назву у зв'язку з тюрк. kul 'рука' (Трубачев 1968: 139), не розкриваючи деталей мотивації семантики гідронімооснови Кул-. Погоджуємося 3 дослідником щодо тюркської генези назви Кула, але вважаємо, що іï етимон слід пов’язувати не з тюрк. kul 'рука', а з тюрк. кула 'сповзати, перестрибувати', ‘кидати донизу', ‘сковзати, плисти’ (Радлов II: 968) на позначення характерних ознак течії гідрооб'єкта. Менш імовірний зв’язок гідроніма Кула 3 тюрк. кула 'жовто-сірий', 'гнідий' (про масть коня) (Радлов II: 967), оскільки цей прикметник вживається на позначення масті коней, а не кольорового відтінку води чи берегового грунту, наприклад: кула ат 'буланий кінь', курт кула 'гнідий кінь із сірими плямами' (Радлов II: 967-968). 
У бас. Дністра відзначено також гідроніми, які не мають однозначної етимології. 3 одного боку, їх можна кваліфікувати як романізми, а 3 другого - як давні слов'янізми або ж тюркізми. I в першому, і в другому випадках ці назви гідрооб'єктів зазнали, напевно, адаптації своєї структури до топонімної системи того мікроареалу, у якому відбувалося їх становлення. Назва б. Реїна (п. Чорної Долини, бас. Дністра; Одеськ. обл.) відзначена в «Атласе новоприобретенной области от Порты Оттоманской и присоединенной к Екатеринославскому наместничеству» (близько 1791 р.) у формі Реина (ГНП 1981: 72). На думку авторів «Гідронімії Нижнього Подністров’я», гідронім Реїна/Реина може відбивати неповний запис молд. реынноит 'відновлений' (ГНП 1981: 72). Таке пояснення малопереконливе з огляду на: 1) гіпотетичність неповного запису молд. реынноum як реыл- і утворення на базі цього структурного елемента гідроніма Рё̈на; 2) незрозумілість мотивації семантики гідронімооснови Рё̈н- ознакою 'відновлена'. Принаймні таке тлумачення доонімного змісту назви гідрооб’єкта не підтверджують споріднені потамоніми. У зв'язку з цим гідронім Реїна, якщо це, звичайно, графічно не спотворена назва, можна етимологізувати як даній слов'янізм у бас. Нижнього Дністра, припускаючи його постання з псл. *rějina (< *rějati 'штовхати, гнати', пор. д.-рус. рғвяти 'штовхати, розштовхувати, відганяти'; ЕСУМ 5: 98). Голосний $е$ в корені гідроніма Реїна (псл. *е̌ > укр. $i$, за винятком деяких діалектів) можна пояснити або впливом російської мови (гідронім зафіксовано в російському джерелі), у якій *е̌ > $e$, або фонетичною адаптацією на східнороманському грунті, пор. гідронім Ренескурт у бас. Нижнього Дністра, перший компонент якого Рене- Ю.О. Карпенко виводив від д.-рус. рғнь 'мілина, низький берег' > рен- у східнороманському мовному середовищі ще до переходу $ъ>i$ в українській мові (Карпенко 1986: 38). Таким чином, Реїна (Реина) <*еејіna на позначення швидкої течії річки. 3 огляду на зазначене припускаємо, що в минулому балка Рё̈н була річкою зі швидкою течією. Етимологічний зв’язок гідроніма Рё̈на з рос. діал. ре́ина 'шибениця' (СРНГ 35: 43) малоймовірний із семантичних міркувань. Гідронім Саполій (пот., л. Мизунки л. Свічі п. Дністра; Івано-Франківськ. обл. (СГУ 1979: 487); варіанти Sapolei, Sopolei; SG X: 305) з погляду структури можна трактувати як східнороманський (румунський) за походженням. На це вказує як етимологічно незрозуміла на слов'янському грунті основа Сапол-/Сопол- (зв'язок зі слов'янською лексикою, похідною від основи *sopěl- (пор. укр. діал. сопи́лка 'місце, яке не замерзає') < *sopěti ‘сопіти’ (ЕСУМ 5: 535) малопереконливий через структурно-фонетичні причини), так і поширеність у східнороманському топоніміконі утворень із суфіксом -ій/-ія (Думін 1969: 157). Формально гідронімооснову Саполможна порівнювати з румун. sapă ‘мотика; обкопування, прополювання', точніше із суфіксально розширеною формою sapăliga 'мотика, кирка' (РУС 1964: 408), відновлюючи імовірну семантику *‘потік із перекопаним річищем’, пор. споріднені укр. гідроніми Перекі́n у бас. Середн. Дністра, Тиси, Тетерева, Переко́пана в бас. Дніпра (СГУ 1979: 416). Однак така етимологія, як слушно зауважує М.М. Габорак, неостаточна (щоправда, автор не пропонує альтернативного пояснення; Габорак 2010: 405). На думку, В.Е. Орла, прикарпатський гідронім Саполій - це 
назва 3 трансформованою структурою, що розвинулася 3 первісного *sQpolbje > poc. діал. суполье 'сусіднє поле', пор. ще споріднений пол. гідронім Sapolna (Орел 1993: 159). Таке пояснення можливе, проте потребує певної аргументаціiі. По-перше, слід пояснити, чому псл. $Q>o$ в префіксальному $* s Q$ - (у такому разі базова форма Сополій). По-друге, з'ясувати причини реалізації -bj- > -iй-. Рефлексація $Q>$ > можлива, якщо припускати деетимологізацію основи і зближення іiі з якимось зовні схожим словом, пор., наприклад, гідронім Соболь у бас. Дністра, який O.M. Трубачов зводив до псл. *sqbol- < *bolto (Трубачев 1968: 263). У разі еволюції гідроніма Сополій із * Супольє важко визначити таку співзвучну лексему. Фонетична зміна -bj- > -ій могла відбутися під впливом східнороманських утворень із суфіксом -ій (див. вище). М.М. Габорак фіксує для гідроніма Саполій/Сополій також варіант Сапотей (Габорак 2010: 405), що уможливлює й іншу етимологію цієї назви - як видозміненої на східнороманському грунті форми від укр. Conim (пор., наприклад, гідронім Cónim - пот., п. Стрия п. Дністра; с. Conim Сколівськ. р-ну Львівськ. обл.; СГУ 1979: 521) < Conomъ < псл. *sopots ‘джерело, струмок' (Трубачев 2003: 141). Назву р. Скиноса (л. Когильника, вп. в лиман Сасик між рр. Прут і Дністер; Одеськ. обл.; варіанти Скиноаса, Скінос; СГУ 1979: 507) М.В. Сергієвський відносив до генетично молдавських гідронімів (Сергиевский 1946: 335), не розкриваючи, щоправда, iї етимона. А. Єремія також пояснював цю назву на східнороманському мовному грунті, пов'язуючи іії $з$ молд. скин < спин 'колючка; чортополох' (Еремия 1970: 68). Таке тлумачення базоване, очевидно, на діалектній фонетиці молдавської мови, у якій відбито субституцію $\kappa$ ‘ ‘ ‘ $n$ (Удлер 1967: 179). Однак східнороманська етимологія гідроніма Скиноса неостаточна, оскільки його можна аналізувати і як адаптовану в молдавськомовному оточенні давнішу тюркську (ногайську) назву гідрооб'єкта Эски-Онус (Харюков 1974: 42) > Скинос (див. вище варіант Скінос), пристосовану до утворень із фіналлю -оасэ - показник жін. р. щодо форм на -ос, пор., наприклад, молд. петрос (чол. р.) - петроасэ (жін. р.; МРС 1961: 461). Топонім Эски-Онус слід розглядати в колі структурно споріднених кримськотатарських назв із першим компонентом eski 'старий’: м. Eski Qirim (Старий Крим), сс. Ескі-Алікеч, ЕскіДжсабач та ін. (Бушаков 2003: 104).

Етимологічний аналіз гідронімів басейну Дністра, сформованих унаслідок східнороманського впливу на словник місцевого українського населення Прикарпаття й Нижньої Наддністрянщини та прилеглих територій, дав змогу виокремити сім структурно-семантичних типів назв гідрооб'єктів: 1) гідроніми, мотивовані відповідними східнороманськими апелятивами з географічною семантикою, а також загальновживаними лексемами, що характеризують форму гідрооб'єкта, кольоровий відтінок води, берегового грунту тощо: Балта, Бульбонія, Бурбоня, Брезой, Бряза, Гирла, Гертіп, Гладиш, Лак, Ларга, Миндра, Пуичита, Сарата, Скурта, Сальча, Стримба, Тятра, Фонтан, Фрасине та ін.; 2) відтопонімні гідроніми: Барабой, Грун(ь), Кетрос, Кетроса, Магура, Секуль, Тусуль, Царилунга, Чербуль, Шептередюр та ін.; 3) відантропонімні гідроніми (мотивовані східнороманськими особовими назвами): Боборязове, Гарасимос, 
Гингурянове, Дегусарова, Драган, Жікулова, Кантемир, Катирева, Пражелова, Рапанова, Ставрова, Темуи, Цуиуроя та ін.; 4) гідроніми зі східнороманськими твірними основами, оформленими слов'янськими афіксами: Копачанка, Кримпулька, Пантирець, Пугайна, Томнатищький (Звір), Царинка та ін.; 5) генетично слов'янські назви гідро- і суміжних топооб'єктів, структурно (фонетика, морфологія, словотвір) адаптовані на східнороманському мовному грунті: Болата, Броничара, Зборшора, Корманул, Крухля, Реуцель та ін.; 6) генетично тюркські гідроніми (топоніми), на формальній структурі яких позначився східнороманський мовний вплив: Кайнарулуй, Кулишора, Козлита та ін.; 7) етимологічно неоднозначні гідроніми: Прадина, Рё̈на, Саполій, Скиноса. Результати дослідження цих гідронімів уможливлюють такі висновки: 1) значна частина аналізованих назв постала на базі прямих запозичень східнороманських (румунських і молдавських) мовних елементів у контактних українських говорах Карпатського регіону (здебільшого буковинських і гуцульських) й межиріччя Пруту й Нижнього Дністра. Це своєрідні лексико-семантичні інновації в місцевій (переважно слов'янській у прикарпатській частині Дністра) топонімній системі, джерелом яких стало східнороманське мовне середовище; 2) ряд гідронімів можна кваліфікувати як гібридні, у структурі яких відбиті слов'янські й східнороманські мовні елементи або генетично тюркські й східнороманські; 3) у складі цілісного гідронімікону бас. Дністра відсоток східнороманських і адаптованих на східнороманському грунті назв незначний (близько 150), хронологічні межі становлення яких можна окреслити в прикарпатській частині Дністра періодом XIII-XVIII ст. (до XIII ст. у цьому регіоні компактних зон поширення румунської мови не було; Шевельов 2002: 988), у межиріччі Пруту й Нижнього Дністра кін. XIV - XVIII ст.

\section{Література. Джерела}

БУШАКОВ, Валерій (2003) Лексичний склад історичної топонімії Криму. Київ: Ін-т сходознавства.

ГАБОРАК, Мирослав (2008) Назви гір $і$ полонин Івано-Франківщини. Словникдовідник. Вид. 2-ге, доп., уточн. Івано-Франківськ: Місто НВ.

ГАБОРАК, Мирослав (2010) Гідронімія Івано-Франківщини. Етимологічний словник-довідник. Вид. 2-ге, доп., переробл., уточн. Івано-Франківськ: Місто НВ.

ГЕРМАН, Костянтин (1973) «Оронимы-карпатизмы в украинских говорах Северной Буковины.» У: Симпозиум по проблемам карпатского языкознания (24-26 апреля 1973 г.): Тэзисы докл. и сообщ./Отв. ред. С.Б. Бернштейн. Москва: Наука, 10-11.

ГЕРМАН, Костянтин (2010) «Українсько-романські міждіалектні взаємини в говірках Буковини.» У: Діалектологічні студії. 9: Запозичення та інтерференція/ред. П. Гриценко, Н. Хобзей. Львів: Ін-т українознавства ім. I. Крип'якевича, 36-44. 
ГНП (1981) Гідронімія Нижнього Подністров'я/Ред. Ю.О. Карпенко. Київ, Одеса: Вища школа.

ДЕСНИЦКАЯ, Агния (2004) «Балканизмы в лексике языков карпатского ареала.» B: Десницкая А.В. Сравнительное языкознание и история языков (изд. 2-е, испр.). Москва: Едиториал УРСС, 295-317.

ДЗЕНДЗЕЛІВСЬКИЙ, Йосип (1959) «Вівчарська лексика говорів Закарпатської області.» У: Доповіді та повідомлення Ужгородського держ. ун-ту. Серія філологічна. №4. Ужгород: В-во Ужгородськ. нац. ун-ту, 107-112.

ДС (1969) Древнетюркский словарь/В.М. Наделяев и др. Ленинград: Наука.

ДУМІН, Богдан (1969) «До топонімії Українських Карпат.» У: Питання географіi Украӥнських Kapnaт. Географічний збірник № 9. Львів: Львів. держ. ун-т ім. I. Франка, 155-161.

ЕРЕМИЯ, Анатолий (1970) Нумэ де локалитэиь. Студиу де топонимие молдовеняскэ. Кишинэу: Штиинца.

ЕРЕМИЯ, Анатолий (1990) Географические названия рассказыьвают. - 2-е изд., перераб. и доп. Кишинев: Штиинца.

ЕСУМ (1982-2012) Етимологічний словник украӥнської мови: $B 7$ m./Ред. О.С. Мельничук. Т. 1-6-. Київ: Наукова думка.

ЗЕЛЕНКО, Лариса, КАСІМ, Галина (1999) «Словник гідронімів верхньої частини басейну Тилігулу.» У: Записки з ономастики. Вип. 1/Ред. Ю.О. Карпенко. Одеса: ОНУ ім. І.І. Мечникова, 92-104.

ЗЕЛЕНКО, Лариса, КАСІМ, Галина (1999а) «Гідронімія нижньої частини басейну Тилігулу.» У: Записки з ономастики. Вип. 3/Ред. Ю.О. Карпенко. Одеса: ОНУ ім. І.І. Мечникова, 88-103.

КАРПЕНКО, Юрій (1973) Топонімія Буковини. Київ: Наукова думка.

КАРПЕНКО, Юрий (1986) «Проблема древнерусских гидронимов в бассейне Нижнего Днестра.» У: Давньоруська ономастична спадщина в східнослов'янських мовах/Ред. В.В. Німчук. Київ: Наукова думка, 34-40.

КАРПЕНКО, Юрій (2005) «Етнічна історія Українських Карпат за даними гідронімії та оронімії.» У: Студії з ономастики та етимології. 2005/Ред. В.П. Шульгач. Київ: Академперіодика, 63-79.

КЛЕПИКОВА, Галина (1972) «О карпатоукраинской терминологии горного ландшафта.» У: Карпатская диалектология и ономастика/Ред. Г.П. Клепикова. Москва: Наука, 51-117.

КЛЕПИКОВА, Галина (1976) «Функционирование и генезис пастушеской терминологии в славянских говорах Карпатского ареала (на украинском диалектном материале).» У: Карпатский сборник: Труды Междунар. комиссии по изучению народной культуры Карпат и прилегающих к ним областей. Москва: Наука, 22-26.

КЛЕПИКОВА, Галина (2007) «Межъязыковое влияние в Карпато-Балканском ареале.» У: Межъъязыковое влияние в истории славянских языков и диалектов: соииокультурный аспект/Ред. Т.И. Вендина. Москва: Инст. славяноведения PAH, 301-350. 
КОЗЛОВА, Раиса (1997) Структура праславянского слова (Праславянское слово в генетическом гнезде). Гомель: Гомельский гос. ун-т им. Ф. Скорины.

КОЗЛОВА, Раиса (2006) Славянская гидронимия. Праславянский фонд. T. IV. Минск: ИООО «Право и экономика».

КУРКИНА, Любовь (1979) «Названия горного рельефа (на материале южнославянских языков).» У: Этимология. 1977/Ред. О.Н. Трубачев. Москва: Наука, 39-54.

МАРУСЕНКО, Татьяна (1968) «Материалы к словарю украинских географических апеллятивов (названия рельефов).»У: Полесье: Лингвистика. Археология. Топонимика/Ред. Н.И. Толстой, В.В. Мартынов. Москва: Наука, 206-255.

МАТІїВ, Микола (1999) Словник гідронімів басейну ріки Стрий. Сімферополь: Кримське навчально-педагогічне державне видавництво.

МРС (1961) Молдавско-русский словарь/А.Т. Борщ и др. Москва: Гос. изд-во иностр. и нац. словарей.

МОХОВ, Николай (1978) Очерки истории формирования молдавского народа. Кишинев: Картя Молдовеняскэ.

МУРЗАЕВ, Эдуард (1989) Словарь народных географических терминов. Москва: Мысль.

ОАІУМ Ономастичний архів Інституту украйнської мови НАН України. Київ

ОБРУЧАР, Аліна (2007) «Мікротопонімія Українського Потисся у ії взаєминах 3 ономастикою суміжних ареалів.» У: Науковий вісник Чернівеиьького унmу. Слов'янська філологія/Наук. ред. Б.І. Бунчук. Вип. 356-359. Чернівці: Чернівецьк. нац. ун-т, 36-41.

ОРЕЛ, Владимир (1993) «Гидронимия славяно-восточнороманского пограничья: бассейн Днестра.» У: Общеславянский лингвистический атлас: Материалы и исследования. 1988-1990/Отв. ред. В.В. Иванов. Москва: Наука, 156-166.

ПАВЛЮК, Е. (1969) «Українсько-молдавська взаємодія в географічній термінології на Буковині.» У: IV Республ. ономастична конферениія: Тези/Відп. ред. К.К. Цілуйко. Київ: Наукова думка, 76-78.

РАДЛОВ, Василий (1893-1911) Oпыт словаря тюркских наречий. T. I-IV. СанктПетербург: Типография Императорской Академии наук.

РУДНИЦЬКИЙ, Ярослав (1962) Географічні назви Бойківщини (вид. 2-ге). Вінніпег: Накладом УВАН.

РУС (1963) Румунсько-украйнський словник. Бухарест: Учбово-педагогічне в-во.

СГУ (1979) Словник гідронімів Украӥни/Ред. А.П. Непокупний та ін. Київ: Наукова думка.

СЕРГИЕВСКИЙ, Максим (1946) «Топонимия Бессарабии и ее свидетельство о процессе заселения территории.» У: Известия АН СССР. Отделение литературы и языка. T. V. Вып. 4. Москва: Изд-во АН СССР, 333-350.

СРНГ (1966-2013) Словарь русских народных говоров. Вып. 1-46-/Ред. Ф.П. Филин и др. Москва, Ленинград, Санкт-Петербург: Наука.

СТРИЖАК, Олексій (1965) «Полтавсько-слобожанські груні.» У: Територіальні діалекти і власні назви/Ред. К.К. Цілуйко. Київ: Наукова думка, 178-192. 
СУГО (2011) Словник украӥнських говорів Одещини/Ред. О.І. Бондар. Одеса: ОНУ ім. І.І. Мечникова.

ТРУБАЧЕВ, Олег (1968) Названия рек Правобережной Украины: Словообразование. Этимология. Этническая интерпретация. Москва: Наука.

ТРУБАЧЕВ, Олег (2003) Этногенез и культура древнейших славян. Лингвистические исследования (изд. 2-е, дополн.). Москва: Наука.

ТУЧИНСьКИЙ, Віталій (2007) Молдавани Півдня Украӥни з найдавніших часів до початку XX cm. Вінниця: О. Власюк.

УДЛЕР, Рубин (1967) «Инфлуенце речипроче молдо-украинене ын райоанеле перифериче.» У: Восточнославяно-молдавские языковые взаимоотношения./ Ред. С.Г. Бережан и др. Кишинев: Штиинца, 170-179.

УДЛЕР, Рубин (1976) «Значение восточнороманского языкового элемента в 'Общекарпатском диалектологическом атласе'.» У: Общекарпатский диалектологический атлас. Лингвистические и этнографические аспекты/Ред. С.Б. Бернштейн. Кишинев: Штиинца, 27-36.

ФАСМЕР, Макс (1964-1973). Этимологический словарь русского языка. T. I-IV/ Перевод с нем. О.Н. Трубачева. Москва: Прогресс.

ХАРЮКОВ, А. (1974) «Татаро-ногайская топонимия Буджака (Советская Придунайщина).» У: Питання ономастики Південної України: Доповіді та повідомлення V Міжвуз. ономастичної конференції (Миколаїв, травень 1974 p.)/Відп. ред. К.К. Цілуйко. Київ: Наукова думка, 40-43.

ЧЕХОВСЬКИЙ, Ігор (1996) Мікротопонімія Чернівещької області в історичному aсnекті/Дисертація наук. ступеня канд. істор. наук. Чернівці.

ШЕВЕЛЬОВ, Юрій (2002) Історична фонологія української мови/Перекл. з англ. С. Вакуленко, А. Даниленко. Харків: Акта.

GOŁĄB, Zbigniew (1959) «Karpacki grun.» У: Onomastica. R. V. Z. 2, 293-309.

HRABEC, Stefan (1950) Nazwy geograficzne Huculszczyzny. Kraków: Pol. Akad. Umiejętności.

IORDAN, Jorgu (1963) Toponimia Rominească. Bucureşti: EARPR.

SG (1880-1902) Stownik geograficzny Królestwa Polskiego i innych krajów Stowiańskich. T. I-XV. Warszawa: Nakł. F. Sulimierskiego, W. Walewskiego.

VRABIE, Emil (2001) Etimologii romăneşti şi străine. Bucureşti: Editura Univers Enciclopedic.

WRG (1961-1969) Wörterbuch der Russischen Gewässernamen/Begr. von M. Vasmer. $B d . I-V$. Berlin, Wiesbaden: Otto Harrasowitz. 


\section{Аннотація \\ СЛОВ'ЯНСЬКО-СХІДНОРОМАНСЬКА ВЗАЄМОДІЯ В ГІДРОНІМІЇ БАСЕЙНУ ДНІСТРА: ОРИГІНАЛЬНІ НАЗВИ ТА СТРУКТУРНО АДАПТОВАНІ УТВОРЕННЯ}

У пропонованій статті досліджено гідроніми басейну Дністра, у структурі яких відбиті східнороманські мовні елементи - цілісні лексеми, основи, афікси, а також назви гідрооб'єктів (генетично слов'янські, тюркські), адаптовані до східнороманської мовної системи. Особливу увагу акцентовано на кількісно найбільшій групі назв із східнороманськими формальними ознаками, що постали способом онімізації відповідних географічних апелятивів (а також загальновживаних лексем на позначення розміру, форми чи інших якісних ознак гідрооб'єкта) або трансонімізації суміжних топонімів (мікротопонімів, оронімів), похідних від лексем із переважно географічною семантикою. На підставі етимологічного аналізу східнороманського фрагмента дністерського гідронімікону зроблено висновок, що тривалі українсько-молдавські й українсько-румунські взаємини позначилися не лише на східнороманських запозиченнях в апелятивний словник української мови, але й на становленні топонімікону в ареалі басейну Дністра, найбільшою мірою в його нижній частині. Щоправда, відсоток східнороманських і адаптованих на східнороманському грунті гідронімів незначний (близько 150), хронологічні межі становлення яких можна окреслити в прикарпатській частині Дністра періодом XIII-XVIII ст., у межиріччі Пруту й Нижнього Дністра - кін. XIV - XVIII ст.

Ключові слова: волоська колонізація, географічний апелятив, гідронім, етимологія, українсько-молдавські та українсько-румунські контакти, фонетична, морфологічна, семантична адаптація структури гідронімів

\section{Abstract \\ SLAVIC AND EASTERN ROMANCE INTERACTION IN THE HYDRONYMY OF THE DNIESTER RIVER BASIN}

The article describes Slavic and Eastern Romance language contact in the Dniester river basin. We investigate the etymology of the hydronyms that have Eastern Romance (Romanian and Moldavian) language elements in their structure. We analzse how water bodies' names (Slavic and Turkic) were adapted in the Eastern Romance linguistic system. It should be stressed that the number of Eastern Romance names as well as names which were adapted to Eastern Romance in the composition of hydronymy the Dniester river basin is insignificant (about 150). The chronological boundary of the formation of these names in the Carpathian part of the Dniester basin is the period from the thirteenth to the eighteenth centuries and the fourteenth to the eighteenth centuries for the area between the Prut and the Lower Dniester. 
Keywords: hydronymy, the Dniester, Slavic and Eastern Romance language interaction, Wallachian colonization of Eastern Carpathians

\section{Povzetek \\ SLOVANSKO-VZHODNOROMANSKI MEDSEBOJNI VPLIV V HIDRONIMIJI DNESTRA: IZVIRNA IMENA IN STRUKTURNO ADAPTIRANE TVORJENKE}

V prispevku so obravnavani hidronimi porečja Dnestra, ki v svoji strukturi odražajo vzhodnoromanske jezikovne prvine: celotni leksemi, osnove, afiksi, obenem pa tudi imena vodnih objektov (genetsko slovanska, turko-tatarska), prilagojena vzhodnoromanskemu jezikovnemu sistemu. Posebna pozornost je posvečena največji skupini imen z vzhodnoromanskimi formalnimi značilnostmi, ki so nastala $\mathrm{z}$ onimizacijo ustreznih geografskih apelativov (pa tudi splošno rabljenih leksemov za zaznamovanje velikosti, oblike ali drugih kakovostnih značilnosti vodnega objekta) ali s transonimizacijo bližnjih toponimov (mikrotoponimov, oronimov), izpeljanih iz leksemov s pretežno geografsko semantiko. Na podlagi etimološke analize vzhodnoromanskega fragmenta dnestrskega hidronimikona je ugotovljeno, da so se dolgotrajni ukrajinskomoldavski in ukrajinsko-romunski stiki odrazili ne le na vzhodnoromanskih izposojenkah $\mathrm{v}$ apelativnem fondu ukrajinskega jezika, temveč so vplivali tudi na oblikovanje toponimikona v porečju Dnestra, še zlasti v njegovem spodnjem delu. Delež vzhodnoromanskih in na vzhodnoromanski podlagi adaptiranih hidronimov resda ni velik (okrog 150 enot), kronološke meje njihovega nastanka pa je v prikarpatskem delu Dnestra mogoče postaviti v obdobje 13.-18. stoletja, v medrečju Pruta in Spodnjega Dnestra pa med koncem 14. in 18. stoletjem.

Ključne besede: hidronimija, Dnester, slovanski in vzhodnoromanski jezikovni stiki, vlaška kolonizacija vzhodnih Karpatov 